\title{
PESTICIDES AND TOXIC METALS RESIDUES IN MUSCLE AND LIVER TISSUES OF SHEEP, CATTLE AND DROMEDARY CAMEL IN SAUDI ARABIA
}

\author{
Ahmed M.A. Meligy ${ }^{1,2}$, Abdallah Y. Al-Taher ${ }^{3}$, Mohamed Ismail ${ }^{3}$, \\ Abdelmohsen A. Al-Naeem ${ }^{4}$, Sabry M. El-Bahr ${ }^{3,5 *}$, Waleed R. El-Ghareeb ${ }^{6,7}$
}

${ }^{1}$ Central laboratory, College of Veterinary Medicine, King Faisal University, Saudi Arabia, ${ }^{2}$ Plant Protection Research Institute, Agricultural Research Center, Egypt, ${ }^{3}$ Department of Physiology, Biochemistry and Pharmacology, College of Veterinary Medicine, King Faisal University, Saudi Arabia, ${ }^{4}$ Department Clinical Studies, College of Veterinary Medicine, King Faisal University, Saudi Arabia, ${ }^{5}$ Department of Biochemistry, Faculty of Veterinary Medicine, Alexandria University, Egypt, ${ }^{6}$ Food Control Department, Faculty of Veterinary Medicine, Zagazig University, 44519, Egypt, ${ }^{7}$ Department of Veterinary Public Health and Animal Husbandry, College of Veterinary Medicine, King Faisal University, Saudi Arabia

*Corresponding author, E-mail: sabryelbahr@hotmail.com; selbahar@kfu.edu.sa

\begin{abstract}
Data regarding determination of pesticide residues and toxic elements in edible tissues of different animals particularly in the camels in Eastern region of Saudi Arabia are scarce. Therefore, current study aimed to evaluate levels of forty-five pesticides and heavy metals (lead (Pb); cadmium (Cd); Arsenic (As)) in muscle and liver tissue samples that collected from forty-two animals; sheep $(n=21)$, cattle $(n=11)$ and dromedary camels $(n=10)$ admitted to Al-Ahsa abattoir, Eastern province, Saudi Arabia. Seven of forty-five pesticides residues were detected in tissues by gas chromatographic mass spectrometry (GC/MS). The detected pesticides were organophosphorus (diazinon, profenofos and coumaphos), pyrethroid (cypermethrin, permethrin and lambda-cyhalothrin) and acaricide (amitraz). Diazinon has been detected in both muscle and liver tissues of all examined carcasses. However, other detected residues distributed according to species. All toxic metals have been detected in both muscle and liver tissues of all tested animals. The heavy metal loads were species independent. The concentrations of $\mathrm{Pb}$ and $\mathrm{As}$ in liver tissues were comparable to that of muscle tissues of all tested animals. However, the concentrations of $\mathrm{Cd}$ in liver were significantly higher than that in muscles of all tested animals. All values of detected pesticide residues and heavy metals were below the maximum residue limits (MRLs). In conclusion, pesticide residues and toxic metals were detected in meat and liver tissues of sheep, cattle and dromedary camels that admitted to Al-Ahsa abattoir, Saudi Arabia. The detected pesticides residues and toxic metals were well below MRLs; thereby no risks are associated with its human consumption.
\end{abstract}

Key words: chromatography; residues; toxic elements; meat; pesticides; animals

\section{Introduction}

Received: January 2019

Accepted for publication: February 2019
The use of pesticide increased steadily during 1996-2013 in Saudi Arabia (1). In 2013, the 
total usage of insecticide was 3130.5 tons of active ingredients compare to that during 2012 (2889 tons of active ingredients). The organophosphate ranked first of pesticide used during this period (1). The Date Palme still represents the most important crop cultivated in Al-Ahsa, Eastern Province, Saudi Arabia and an element contributing in economy of the beautiful oasis, Al-Ahsa. Pesticides used in Al-Ahsa to fight the red date Palme weevil (2) and other pests that attack different varieties of vegetable crops cultivated in Al-Ahsa region (1). Contamination of the environment with pesticide residues has been documented earlier (3). Based on the reports of the toxicity and detrimental effects of pesticides, their use has been restricted worldwide. Although the use of most of pesticides has been restricted, its residues in food were detected (4). Water, plants and grasses that contaminated by pesticides residues may ingested by herbivorous animals and secreted in meat and/or milk (4). Pesticides residues contamination has been reported in processed food $(5,6)$ and eggs $(7,8)$. In addition, organochlorine pesticides have been detected in edible tissues of camel, cattle and sheep carcasses slaughtered in Sharkia Province of Egypt (9), in meat of sheep slaughtered in Jaipur area of India (10) and in fish and poultry meat in India (11). The dromedary camels are one of the important sources of meat in the semiarid and arid areas of Asia and Africa (12). Camel meat characters are near to that of other red meat animal species (12). In Al-Ahsa region, camel meat is preferable along with the other meats of sheep and cattle. However, data reporting the detection of pesticides residues in edible tissues of these animals reared in Al-Ahsa region of eastern province of Saudi Arabia are scarce. The inorganic arsenic is more toxic than organic one. However, it is reported in literatures as total arsenic (13). The exposure of animal to lead increased when feed materials mixed with contaminated soil (14). Regarding lead toxicity, cattle and sheep are the most sensitive animal species. The elimination of lead is incomplete and slow. Its half-life is approximately 250 days in ewes, between 95 and 760 days in cattle $(15,16)$, and 2 to 18 years in humans $(17,18)$. Like lead, animal exposed to cadmium through plants mixed with contaminated soil (19). Cadmium classified as a human carcinogen (Group 1) by International Agency of Cancer Research particularly cancer in lungs, endometrial tissue, bladder, and breast (20). Only one report (21) originated from our laboratory demonstrated the detection of metal contents in the edible tissues of camel and sheep slaughtered in Saudi Arabia. However, in this report (21), cattle meat and liver tissues were not investigated. GC-MS used for high speed, excellent separation and quantitative analysis of many volatile pesticides (22-29). The current study aimed to evaluate levels of forty-five pesticides and heavy metals (lead (Pb); cadmium (Cd); Arsenic (As)) in muscle and liver tissue samples that collected from forty-two animals; sheep $(n=21)$, cattle $(n=11)$ and dromedary camels $(n=10)$ admitted to Al-Ahsa abattoir, Eastern province, Saudi Arabia.

\section{Material and methods}

\section{Animals and samples}

Specimens of muscle $(n=42)$ and liver $(n=42)$ tissues have been collected from 42 animals of three species namely sheep $(n=21)$, cattle $(n=11)$ and dromedary camels $(n=10)$ that have been admitted to Al-Ahsa abattoir, Eastern province, Saudi Arabia $\left(25^{\circ} 22^{\prime} 18.1^{\prime \prime} \mathrm{N}\right.$ $\left.49^{\circ} 26^{\prime} 21.1^{\prime \prime} \mathrm{E}\right)$ directly after slaughter. Age of animals was determined by visual examination of teeth during the ante-mortem inspection (25). The average age of the slaughtered camel and cattle was estimated to be $5 \pm 2$ years, respectively while for sheep was and $8 \pm 3$ months. All animals were apparently healthy, active, and free from any disease. Sampled tissues for pesticide and heavy metal residues analysis were stored in plastic falcon tubes and stored at $-20^{\circ} \mathrm{C}$ until the time of extraction and measurement of 45 pesticide and heavy metal residues. The experiments and procedures were done according to the regulations and guidelines of ethical research committee, King Faisal University, Saudi Arabia. All chemicals were purchased from Merck, Darmstadt, Germany and were of HPLC grade or the highest quality available. Specifications for pesticides standards used in the study are illustrated at Table 1. 


\section{Analytical procedure for pesticide residues}

The QuEChERS EN 15662 method for pesticide residue extraction was used (30) and the obtained extracts were transferred to an auto sampler vial of GC-MS for analysis of pesticide residues.Pesticides residues have been detected by GC/MS system (Shimadzu GC/MS-QP2010 Plus, Japan) equipped with a capillary column DB-5MS (30m length, $0.25 \mathrm{~mm}$ thickness, $0.25 \mathrm{~m}$ diameter). The temperature of injector was $250^{\circ} \mathrm{C}$. The temperature program of oven started with $60^{\circ} \mathrm{C}$. Hold $6 \mathrm{~min}$ at $7^{\circ} \mathrm{C} / \mathrm{min}$ to 200 ${ }^{\circ} \mathrm{C}$, at $5^{\circ} \mathrm{C} / \mathrm{min}$ to $280{ }^{\circ} \mathrm{C}$. Hold $20 \mathrm{~min}$; carrier gas, helium; purity, $\geq 99.999 \%$; flow rate, 1.2 $\mathrm{ml} / \mathrm{min}$; injection port temperature, $250^{\circ} \mathrm{C}$; injection volume, 1ul; injection mode, splitless, purge on after $1.5 \mathrm{~min}$; ionization voltage, 70 $\mathrm{eV}$; ion source temperature, $220{ }^{\circ} \mathrm{C}$; GC/MS interface temperature, $250^{\circ} \mathrm{C}$. The analyses were done at two modes, Selective Ion Monitoring (SIM mode) and full Scan mode for enhanced sensitivity and selectivity. The limits of detection (LOD) and limit of quantification (LOQ) for all pesticides are shown in Table 2.

Analysis of heavy metals ( $\mathrm{Pb}, \mathrm{Cd}$ and $\mathrm{As}$ )

The digestion of muscle and liver samples and the GFA-EX7 graphite furnace atomic absorption spectrophotometeic (Shimadzu, Koyoto, Japan) determination of $\mathrm{Pb}, \mathrm{Cd}$ and $\mathrm{As}$ were done as described earlier $(31,32)$. Preparation of standard stock solutions of $\mathrm{Cd}, \mathrm{Pb}$ and As and calibration procedures were the same of that discussed in our previous works $(31,32)$. The LOD for the three investigated heavy metals was $1 \mu \mathrm{g} / \mathrm{kg}$. The absorbance was obtained by adjusting the hollow cathode lamps at the operation conditions shown in Table 3.

Analytical quality control

In the present study, to check the efficiency of digestion procedures and the subsequent recovery of the pesticides and metals, homogeneous mixtures of three samples of each of muscle and liver were spiked with multi-elements and multi-pesticides solutions that contain standard solutions of all pesticides and metals considered in the present study. Solutions were spiked in a manner to attain final concentrations of $3 \mu \mathrm{g} / \mathrm{g}$. A mixture without any pesticides and metals was used as control. All mixtures were then subjected to the digestion procedure. The resulting solutions were analyzed three times for pesticides and metal concentrations according to the same procedures as the samples to establish confidence in the accuracy and reliability of data generated. The amount of spiked pesticides and metals recovered after the digestion of the spiked samples were used to calculate percentage recovery as described earlier (33). The pesticide recovered from both tissues in a percentage over $89 \%$ as indicated at Table 2. All heavy metals recovered in a percentage ranged between (89.6-94.2 \%) and (85-89.4 \%) in liver and muscle tissues, respectively (Table 4).

\section{Specificity}

The specificity was confirmed based on the presence of the transition ions (quantifier and qualifier) at the correct retention times (that was defined formerly by using one sample from each type that spiked at $10 \mathrm{ng} / \mathrm{g}$ to check the retention time of pesticides) corresponding to that of the precursor ion presented in Table 1. The measured peak area ratios of qualifier/quantifier were within the range defined in EU Commission Decision 2002/657/EC when compared to the standards.

\section{Statistical analysis}

The statistical analysis was performed using the SPSS 6.1.3 software package (SAS, Cary, NC, USA). All data were analyzed for variance using ANOVA test.

\section{Results and discussion}

Data summarized in Table 1 and Figure 1 indicated that, the total number of investigated pesticides standards were 45 standards. However, gas chromatographic analysis indicated the existence of only 7 types of pesticides residues (Diazinon, Lambda-Cyhalothrin-II, Profenofos, Cis-Permethrin, Cypermethrin, Amitraz, coumaphos). The aim behind the screening of large number of pesticides was to cover all existing chemical classes that includes, organophosphates, organo-chlorine, carbamates, synthetic pyrethroids, triazines, pyrimidines, triazoles, dicarboximides, bezimid- 
azole, dithiocarbamates, nicotinoids, dinitrophenol, pesticides aliphatic nitrogen, pesticides morpholine, pesticides from natural product derivatives, and pesticides of substituted urea class. However, only seven of screened pesticides have been detected in muscle and liver tissues of all tested animals (Table 1). The detected pesticides residues are of listed pesticides residues monitored in Saudi agricultural soils (34). Diazinon has been detected in muscle and liver tissues of all examined carcasses. This may attributed to the extensive use of diazinon for eradication of Ticks that affected animals related to all areas of Al-Ahsa governorate as said by the habitants of that region. Other detected pesticides residues were species related (Table 5 and 6). Profenofos residues has been detected in examined tissues of sheep and camels whereas, amitraz and permethrin have been detected only in muscle and liver of cattle carcass (Table 5 and 6). Coumaphos detected only in examined tissues of sheep carcass while Lambda-Cyhalothrin residues were detected only in muscle and liver tissues of camel carcass (Tables 5 and 6). The variation of pesticides contamination among tested animals may attribute to different contaminated areas because animals who admitted to Al-Ahsa abattoir were from different areas of Al-Ahsa governorate. The area dependent pesticides contamination has been confirmed in other study in Egypt (35). The data described in Tables 5 and 6 indicated that, all values of detected pesticide residues were below the international permissible limits (14). Parallel to the current findings, earlier report (9) demonstrated that, the organochlorines residues detected in muscle and liver tissues of camel, sheep and cattle were well below the respective MRLs set by local or international organizations. Data summarized in Tables 7 indicated that, the investigated toxic metal residues have been detected in muscle and liver tissues of all examined carcasses. The heavy metal loads were species independent (Tables 7). The concentrations of $\mathrm{Pb}$ and $\mathrm{As}$ in liver tissues were comparable to that of muscle tissues of all tested animals. However, the concentration of $\mathrm{Cd}$ in liver was significantly higher than its concentration in muscle in all tested animals (Tables 7). This may attribute to the fact that, the liver is main organ for detoxification in the live organism (36). The current findings come in accordance with recent work (21) reported that, liver tissues had a higher loads of heavy metals $(\mathrm{Cd}, \mathrm{Pb}$ and $\mathrm{As})$ than that of muscle tissues in camel and sheep slaughtered in the same area of Saudi Arabia. All values of detected heavy metals were well below the international permissible limit as described in Tables 7 (4, 13, 14, 20, 21, 37). The highest detected average of Arsenic, lead and cadmium residues either in muscle or in liver tissues were $11.6 \pm 2.0 \mu \mathrm{g} / \mathrm{kg}, 10.5 \pm 1.8 \mu \mathrm{g} / \mathrm{kg}$ and $0.9 \pm 0.1$ $\mu \mathrm{g} / \mathrm{kg}$ whereas the arsenic, lead and cadmium MRLs are $1000 \mu \mathrm{g} / \mathrm{kg}, \quad 500 \mu \mathrm{g} / \mathrm{kg}$ and $1000 \mu \mathrm{g} / \mathrm{kg}$, respectively. This indicated that, the contaminated tissues with all toxic elements are negligible and safe for human consumption. The detected values of Arsenic, lead and cadmium residues were much lower than that reported in liver and kidney bovine tissues (27.42-30.55 $\mu \mathrm{g} / \mathrm{kg} ; 231-226.96 \mu \mathrm{g} / \mathrm{kg} ; 207.5-$ $197 \mu \mathrm{g} / \mathrm{kg}$; (38), respectively. The wide range between detected elements in the current study compared with earlier report (38) may attribute to different detection limits and sensitivity. Eelier detection limits (38) were $100 \mu \mathrm{g} / \mathrm{kg}$ for $\mathrm{Cd}, 150 \mu \mathrm{g} / \mathrm{kg}$ for $\mathrm{Pb}$ and $30 \mu \mathrm{g} / \mathrm{kg}$ for As. However, in the current study the detection limits were $1 \mu \mathrm{g} / \mathrm{kg}$ for the three investigated elements. The detected values of $\mathrm{Cd}$ and $\mathrm{As}$ in liver of camel $(1.3 \pm 0.1 \mu \mathrm{g} / \mathrm{kg} ; 1.4 \pm 0.4 \mu \mathrm{g} / \mathrm{kg})$ and sheep $(11.6 \pm 2.0 \mu \mathrm{g} / \mathrm{kg} ; 8.0 \pm 2.0 \mu \mathrm{g} / \mathrm{kg})$, respectively were near to that reported recently (21) in liver of camel $(2.18 \pm 0.71 \mu \mathrm{g} / \mathrm{kg} ; 1.79$ $\pm 0.66 \mu \mathrm{g} / \mathrm{kg})$ and sheep $(38.41 \pm 25.15 \mu \mathrm{g} / \mathrm{kg}$; $30.29 \pm 22.57 \mu \mathrm{g} / \mathrm{kg})$, respectively. The values of $\mathrm{Cd}$ and As in the muscle of camel $(0.9 \pm 0.1$ $\mu \mathrm{g} / \mathrm{kg} ; 0.6 \pm 0.1 \mu \mathrm{g} / \mathrm{kg})$ and sheep $(8.0 \pm 1.1$ $\mu \mathrm{g} / \mathrm{kg} ; 6.4 \pm 1.2 \mu \mathrm{g} / \mathrm{kg}$ ) respectively were near to that reported recently (21) in muscle of camel $(0.29 \pm 0.27 \mu \mathrm{g} / \mathrm{kg} ; 0.44 \pm 0.17 \mu \mathrm{g} / \mathrm{kg})$ and sheep $(12.89 \pm 4.24 \mu \mathrm{g} / \mathrm{kg} ; 10.05 \pm 3.77 \mu \mathrm{g} / \mathrm{kg})$, respectively. In the current study, the detected values of $\mathrm{Pb}$ in liver and muscle of camel and sheep were exactly comparable to that reported earlier in the same tissues of the same tested animals (21). 
Table 1: Specifications for pesticides standards used in the study

\begin{tabular}{|c|c|c|c|c|c|c|c|c|c|c|c|}
\hline No & $\begin{array}{l}\text { Name of } \\
\text { pesticide }\end{array}$ & $\begin{array}{l}\text { Re- } \\
\text { tention } \\
\text { time }\end{array}$ & $\begin{array}{l}\text { Quanti- } \\
\text { fying ion }\end{array}$ & $\begin{array}{r}\text { Quali- } \\
\text { fying ion1 }\end{array}$ & $\begin{array}{r}\text { Quali- } \\
\text { fying ion2 }\end{array}$ & No & $\begin{array}{l}\text { Name of } \\
\text { pesticide }\end{array}$ & $\begin{array}{l}\text { Re- } \\
\text { tention } \\
\text { time }\end{array}$ & $\begin{array}{l}\text { Quanti- } \\
\text { fying ion }\end{array}$ & $\begin{array}{r}\text { Quali- } \\
\text { fying ion1 }\end{array}$ & $\begin{array}{r}\text { Quali- } \\
\text { fying ion2 }\end{array}$ \\
\hline 1 & $\begin{array}{l}\text { Demeton-S- } \\
\text { methyl }\end{array}$ & 10.129 & 263 & 169 & 127 & 26 & Propargite-I & 31.003 & 135 & $350(7)$ & 173(16) \\
\hline 2 & $\alpha-\mathrm{HCH}$ & 11.108 & 219 & 183(98) & $221(47)$ & 27 & Profenofos* & 31.382 & 339 & 374 (39) & 297 (37) \\
\hline 3 & Diazinon $*$ & 15.670 & 304 & 179(192) & $137(172)$ & 28 & Bifenthrin & 32.39 & 181 & $166(25)$ & $165(23)$ \\
\hline 4 & HCB & 17.567 & 284 & $282(51)$ & $286(81)$ & 29 & Methoxychor & 32.672 & 277 & $228(16)$ & $212(4)$ \\
\hline 5 & Phorate & 18.271 & 260 & $121(160)$ & $231(156)$ & 30 & Captan & 32.782 & 264 & $149(104)$ & $150(70)$ \\
\hline 6 & $\beta-\mathrm{HCH}$ & 19.954 & 219 & $217(78)$ & 181(94) & 31 & Formothion & 32.884 & 170 & $224(97)$ & $257(63)$ \\
\hline 7 & $\delta-\mathrm{HCH}$ & 20.108 & 219 & $217(80)$ & 181(99) & 32 & p,p'-DDT & 33.108 & 235 & $237(65)$ & $246(7)$ \\
\hline 8 & Heptachlor & 20.503 & 272 & $237(40)$ & $337(27)$ & 33 & p,p'-DDD & 33.232 & 235 & $237(64)$ & 199(12) \\
\hline 9 & Aldrin & 20.743 & 263 & $265(65)$ & 293(40) & 34 & $\begin{array}{l}\text { Cis-Perme- } \\
\text { thrin } *\end{array}$ & 33.759 & 183 & $184(14)$ & $255(1)$ \\
\hline 10 & $\begin{array}{l}\text { Lambda- } \\
\text { Cyhalothrin-II } \\
*\end{array}$ & 22.533 & 181 & $241(205)$ & $243(152)$ & 35 & Captafol & 34.565 & 149 & $150(79)$ & $152(79)$ \\
\hline 11 & $\alpha$-Endosulfan & 23.087 & 241 & $265(66)$ & $339(46)$ & 36 & p.p'-DDE & 36.154 & 318 & $316(80)$ & 246(139) \\
\hline 12 & chlorothalonil & 23.995 & 264 & 266(109) & $268(62)$ & 37 & O',p'-DDD & 36.337 & 235 & $237(65)$ & 165(39) \\
\hline 13 & $\begin{array}{l}\text { Methylpara- } \\
\text { thion }\end{array}$ & 25.056 & 263 & $233(66)$ & $246(8)$ & 38 & $\begin{array}{l}\text { Cyperme- } \\
\text { thrin* }\end{array}$ & 36.457 & 181 & $152(23)$ & $180(16)$ \\
\hline 14 & $\begin{array}{l}\text { Endosulfan } \\
\text { sulfate }\end{array}$ & 25.313 & 241 & $265(66)$ & $339(46)$ & 39 & Amitraz* & 36.613 & 293 & $162(113)$ & $132(104)$ \\
\hline 15 & Dieldrin & 27.196 & 263 & 277(82) & $380(30)$ & 40 & coumaphos* & 37.106 & 362 & $226(56)$ & $364(39)$ \\
\hline 16 & Endrin & 27.432 & 263 & $317(30)$ & $345(26)$ & 41 & $\begin{array}{c}\text { Trans-Perme- } \\
\text { thrin }\end{array}$ & 37.231 & 183 & 184(14) & $255(1)$ \\
\hline 17 & O,p'-DDE & 27.683 & 246 & $318(34)$ & $176(26)$ & 42 & Fenvalerate & 37.317 & 167 & $225(53)$ & 419(37) \\
\hline 18 & Dicofol & 28.104 & 139 & $141(72)$ & $250(23)$ & 43 & Deltamethrin & 37.969 & 181 & $172(25)$ & $174(25)$ \\
\hline 19 & Malathion & 28.418 & 173 & $158(36)$ & $143(15)$ & 44 & Cyfluthrin & 41.512 & 206 & $199(63)$ & $226(72)$ \\
\hline 20 & Fenithrothion & 29.053 & 277 & $260(52)$ & $247(60)$ & 45 & Esfenvalerate & 46.085 & 419 & $225(158)$ & 181(189) \\
\hline 21 & $\begin{array}{l}\text { Bromopropy- } \\
\text { late }\end{array}$ & 29.452 & 341 & $183(34)$ & 339(49) & & & & & & \\
\hline 22 & penconazol & 30.101 & 248 & $250(33)$ & $161(50)$ & & & & & & \\
\hline 23 & $\begin{array}{l}\text { Pirimiphos- } \\
\text { methyl }\end{array}$ & 30.281 & 290 & $276(86)$ & $305(74)$ & & & & & & \\
\hline 24 & Procymidone & 30.448 & 283 & $285(70)$ & $255(15)$ & & & & & & \\
\hline 25 & o,p'-DDT & 30.767 & 235 & $237(65)$ & $246(7)$ & & & & & & \\
\hline
\end{tabular}

*Tissues detected pesticides

Table 2: Limit of Detection (LOD), Limit of Quantification (LOQ) and recovery percentages of pesticide measured using the ions for each pesticide molecule

\begin{tabular}{cccccc}
\hline No & Name of pesticide & RT & LOD $(\mu \mathrm{g} / \mathrm{g})$ & LOQ $(\mu \mathrm{g} / \mathrm{g})$ & Recovery $\%$ \\
\hline 1 & Demeton-S-methyl & 10.129 & 0.02 & 0.06 & 89.2 \\
2 & $\alpha-\mathrm{HCH}$ & 11.108 & 0.02 & 0.06 & 90.2 \\
3 & Diazinon $*$ & 15.670 & 0.006 & 0.017 & 95.0 \\
4 & HCB & 17.567 & 0.02 & 0.06 & 92.1 \\
5 & Phorate & 18.271 & 0.03 & 0.12 & 89.9 \\
6 & $\beta-H C H$ & 19.954 & 0.01 & 0.03 & 90.5 \\
7 & $\delta$-HCH & 20.108 & 0.01 & 0.03 & 90.6 \\
8 & Heptachlor & 20.503 & 0.002 & 0.007 & 92.4 \\
9 & Aldrin & 20.743 & 0.02 & 0.05 & 89.5 \\
10 & Lambda-Cyhalothrin-II $*$ & 22.533 & 0.004 & 0.01 & 91.7 \\
11 & $\alpha-$-Endosulfan & 23.087 & 0.003 & 0.008 & 90.9 \\
12 & chlorothalonil & 23.995 & 0.006 & 0.015 & 93.3 \\
13 & Methylparathion & 25.056 & 0.004 & 0.012 & 94.5 \\
14 & Endosulfan sulfate & 25.313 & 0.002 & 0.006 & 93.4 \\
15 & Dieldrin & 27.196 & 0.02 & 0.008 & 93.1 \\
16 & Endrin & 27.432 & 0.01 & 0.04 & 92.2
\end{tabular}


Table 2: Continuation

\begin{tabular}{lccccc}
\hline No & Name of pesticide & RT & LOD $(\mu \mathrm{g} / \mathrm{g})$ & LOQ $(\mu \mathrm{g} / \mathrm{g})$ & Recovery $\%$ \\
\hline 17 & O,p'-DDE & 27.683 & 0.02 & 0.06 & 90.5 \\
18 & Dicofol & 28.104 & 0.003 & 0.009 & 90.7 \\
19 & Malathion & 28.418 & 0.005 & 0.012 & 90.0 \\
20 & Fenithrothion & 29.053 & 0.004 & 0.013 & 91.9 \\
21 & Bromopropylate & 29.452 & 0.005 & 0.015 & 92.9 \\
22 & penconazol & 30.101 & 0.004 & 0.012 & 93.0 \\
23 & Pirimiphos-methyl & 30.281 & 0.006 & 0.018 & 90,1 \\
24 & Procymidone & 30.448 & 0.01 & 0.030 & 90,7 \\
25 & o,p'-DDT & 30.767 & 0.009 & 0.016 & 91.7 \\
26 & Propargite-I & 31.003 & 0.009 & 0.015 & 91.4 \\
27 & Profenofos* & 31.382 & 0.004 & 0.010 & 92.5 \\
28 & Bifenthrin & 32.39 & 0.002 & 0.006 & 90.4 \\
29 & Methoxychor & 32.672 & 0.006 & 0.012 & 93.7 \\
30 & Captan & 32.782 & 0.01 & 0.03 & 94.0 \\
31 & Formothion & 32.884 & 0.004 & 0.012 & 90.2 \\
32 & p,p'-DDT & 33.108 & 0.002 & 0.006 & 92.9 \\
33 & p,p'-DDD & 33.232 & 0.003 & 0.013 & 91.9 \\
34 & Cis-Permethrin $*$ & 33.759 & 0.004 & 0.010 & 93.7 \\
35 & Captafol & 34.565 & 0.001 & 0.004 & 91,4 \\
36 & p.p'-DDE & 36.154 & 0.004 & 0.011 & 89.8 \\
37 & O',p'-DDD & 36.337 & 0.004 & 0.012 & 89.7 \\
38 & Cypermethrin* & 36.457 & 0.003 & 0.009 & 93.9 \\
39 & Amitraz* & 36.613 & 0.002 & 0.006 & 89.6 \\
40 & coumaphos* & 37.106 & 0.002 & 0.006 & 94.0 \\
41 & Trans-Permethrin & 37.231 & 0.003 & 0.009 & 90.9 \\
42 & Fenvalerate & 37.317 & 0.02 & 0.06 & 90.8 \\
43 & Deltamethrin & 37.969 & 0.002 & 0.007 & 94.3 \\
44 & Cyfluthrin & 41.512 & 0.003 & 0.009 & 90.1 \\
45 & Esfenvalerate & 46.085 & 0.01 & 0.03 & 90.2 \\
\hline
\end{tabular}

*Tissues detected pesticides

Table 3: Programs of heating method of graphite furnace atomic absorption (GFAAS) for Arsenic (As), lead $(\mathrm{Pb})$ and cadmium $(\mathrm{Cd})$

\begin{tabular}{ccccccc}
\hline Steps & \multicolumn{2}{c}{ Temperature $\left({ }^{\circ} \mathrm{C}\right)$} & Ramp(s) & Hold(s) & $\begin{array}{c}\text { Argon flow rate } \\
(\mathrm{ml} \mathrm{min}-1)\end{array}$ \\
\hline & $\mathrm{As}$ & $\mathrm{Pb}$ & $\mathrm{Cd}$ & & & \\
Drying 1 & 150 & 150 & 150 & 5 & 20 & 250 \\
Drying 2 & 200 & 200 & 200 & 5 & 15 & 250 \\
Pyrolysis & 1200 & 800 & 500 & 10 & 20 & 250 \\
Atomization & 2000 & 2000 & 1800 & 0 & 5 & 0 \\
Clean-out & 2000 & 2200 & 2200 & 1 & 3 & 250 \\
\hline
\end{tabular}


Table 4: The recovery of heavy metals ( $\mathrm{As}, \mathrm{Pb}$ and $\mathrm{Cd}$ ) from digested liver and muscle samples:-

\begin{tabular}{cccccc}
\hline $\begin{array}{l}\text { Heavy } \\
\text { metals }\end{array}$ & $\begin{array}{c}\text { Added Heavy } \\
\text { metals }(\mu \mathrm{g} / \mathrm{kg})\end{array}$ & $\begin{array}{c}\text { Recovered from } \\
\text { liver }(\mu \mathrm{g} / \mathrm{kg})\end{array}$ & $\begin{array}{c}\text { Recovery } \\
(\%)\end{array}$ & $\begin{array}{c}\text { Recovered from mus- } \\
\text { cle }(\mu \mathrm{g} / \mathrm{kg})\end{array}$ & $\begin{array}{c}\text { Recovery } \\
(\%)\end{array}$ \\
\hline $\mathrm{As}$ & 5 & 4.47 & 89.6 & 4.39 & 89.4 \\
$\mathrm{~Pb}$ & 5 & 4.69 & 94.2 & 4.44 & 88.8 \\
$\mathrm{Cd}$ & 5 & 4.66 & 93 & 4.25 & 85 \\
\hline
\end{tabular}

AS: (Arsenic); Pb: Lead; Cd: Cadmium

Table 5: Pesticides residues $(\mathrm{mg} / \mathrm{kg})$ detected in muscle tissues $(\mathrm{n}=42)$ of sheep, cattle and dromedary camels admitted to Al-Ahsa Abattoir, Saudi Arabia

\begin{tabular}{|c|c|c|c|c|c|c|c|}
\hline $\begin{array}{l}\text { Animal } \\
\text { Species }\end{array}$ & $\begin{array}{l}\text { No. of } \\
\text { Animals } \\
\text { tested }\end{array}$ & $\begin{array}{c}\text { No. of } \\
\text { samples }\end{array}$ & $\begin{array}{l}\text { No of Res- } \\
\text { idues con- } \\
\text { taining } \\
\text { samples }\end{array}$ & $\begin{array}{l}\text { No of de- } \\
\text { tected } \\
\text { pesticides } \\
\text { residues }\end{array}$ & $\begin{array}{l}\text { Types of detected } \\
\text { pesticides residues }\end{array}$ & $\begin{array}{c}\text { Concentration } \\
\text { of detected } \\
\text { pesticides } \\
\text { residues }\end{array}$ & $\begin{array}{l}\text { Permissible } \\
\text { limit }(13,14)\end{array}$ \\
\hline \multirow{4}{*}{ Sheep } & \multirow{4}{*}{21} & \multirow{4}{*}{21} & \multirow{4}{*}{1} & \multirow{4}{*}{ 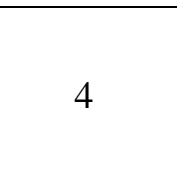 } & Diazinon & 0.005 & 0.02 \\
\hline & & & & & Profenofos & 0.015 & 0.05 \\
\hline & & & & & Cypermethrin & 0.009 & 0.20 \\
\hline & & & & & Caumaphos & 0.018 & 0.01 \\
\hline \multirow{4}{*}{ Cattle } & \multirow{4}{*}{10} & \multirow{4}{*}{10} & \multirow{4}{*}{3} & \multirow{4}{*}{4} & Diazinon & 0.017 & 0.02 \\
\hline & & & & & Cypermethrin & 0.035 & 0.20 \\
\hline & & & & & Amitraz & 0.033 & 0.02 \\
\hline & & & & & Permethrin & 0.029 & 0.50 \\
\hline \multirow{3}{*}{ Camel } & \multirow{3}{*}{11} & \multirow{3}{*}{11} & \multirow{3}{*}{2} & \multirow{3}{*}{3} & Diazinon & 0.018 & 0.02 \\
\hline & & & & & Profenofos & 0.019 & 0.05 \\
\hline & & & & & Lambda-Cyhalothrin & 0.033 & 0.50 \\
\hline
\end{tabular}

Table 6: Pesticides residues $(\mathrm{mg} / \mathrm{kg})$ detected in Liver tissues $(\mathrm{n}=42)$ of sheep, cattle and dromedary camels admitted to Al-Ahsa Abattoir,Saudi Arabia.

\begin{tabular}{|c|c|c|c|c|c|c|c|}
\hline $\begin{array}{l}\text { Animal } \\
\text { Species }\end{array}$ & $\begin{array}{c}\text { No. of } \\
\text { Animals } \\
\text { tested }\end{array}$ & $\begin{array}{c}\text { No. of } \\
\text { samples }\end{array}$ & $\begin{array}{l}\text { No of Resi- } \\
\text { dues con- } \\
\text { taining } \\
\text { samples }\end{array}$ & $\begin{array}{l}\text { No of de- } \\
\text { tected pes- } \\
\text { ticides } \\
\text { residues }\end{array}$ & $\begin{array}{l}\text { Types of detected pes- } \\
\text { ticides residues }\end{array}$ & $\begin{array}{l}\text { Concentration } \\
\text { of detected pes- } \\
\text { ticides residues }\end{array}$ & $\begin{array}{l}\text { Permissible } \\
\text { limit }(13,14)\end{array}$ \\
\hline \multirow{4}{*}{ Sheep } & \multirow{4}{*}{21} & \multirow{4}{*}{21} & \multirow{4}{*}{3} & \multirow{4}{*}{4} & Diazinon & 0.012 & 0.02 \\
\hline & & & & & Profenofos & 0.022 & 0.05 \\
\hline & & & & & Cypermethrin & 0.015 & 0.05 \\
\hline & & & & & Coumaphos & 0.024 & 0.01 \\
\hline \multirow{4}{*}{ Cattle } & \multirow{4}{*}{10} & \multirow{4}{*}{10} & \multirow{4}{*}{3} & \multirow{4}{*}{4} & Diazinon & 0.034 & 0.02 \\
\hline & & & & & Cypermethrin & 0.041 & 0.02 \\
\hline & & & & & Amitraz & 0.023 & 0.20 \\
\hline & & & & & Permethrin & 0.014 & 0.05 \\
\hline \multirow{3}{*}{ Camel } & \multirow{3}{*}{11} & \multirow{3}{*}{11} & \multirow{3}{*}{2} & \multirow{3}{*}{3} & Diazinon & 0.027 & 0.02 \\
\hline & & & & & Profenofos & 0.029 & 0.05 \\
\hline & & & & & Lambda-Cyhalothrin & 0.053 & 0.50 \\
\hline
\end{tabular}


Table 7: Heavy metals $(\mu \mathrm{g} / \mathrm{kg})$ detected in muscleand liver tissues $(\mathrm{n}=42)$ of sheep, cattle and dromedary camels admitted to Al-Ahsa Abattoir, Saudi Arabia.

\begin{tabular}{|c|c|c|c|c|c|c|c|c|}
\hline \multirow[b]{2}{*}{$\begin{array}{l}\text { Animal } \\
\text { Species }\end{array}$} & \multirow[b]{2}{*}{$\begin{array}{l}\text { No. of An- } \\
\text { imals } \\
\text { tested }\end{array}$} & \multirow[b]{2}{*}{$\begin{array}{l}\text { No. of } \\
\text { samples }\end{array}$} & \multicolumn{6}{|c|}{ Heavy metals concentration (ppb) } \\
\hline & & & $\begin{array}{c}{ }^{*} \mathrm{~Pb} \text { in muscle } \\
\text { tissues }\end{array}$ & $\begin{array}{l}\mathrm{Pb} \text { in liver } \\
\text { tissues }\end{array}$ & $\begin{array}{l}{ }^{\dagger} \mathrm{Cd} \text { in } \\
\text { muscle tis- } \\
\text { sues }\end{array}$ & $\begin{array}{l}\mathrm{Cd} \text { in liver } \\
\text { tissues }\end{array}$ & $\begin{array}{l}\ddagger \text { As in mus- } \\
\text { cle tissues }\end{array}$ & $\begin{array}{l}\text { As in liver } \\
\text { tissues }\end{array}$ \\
\hline & & & & & $0.6 \pm 0.1^{\mathrm{ax}}$ & & & \\
\hline & & 0 & & & $0.7 \pm 0.2^{\mathrm{ax}}$ & & & $2.5^{\mathrm{aw}}$ \\
\hline Camel & 11 & 11 & $7.30 \pm 1.20^{\mathrm{aw}}$ & $10.5 \pm 1.8^{\mathrm{aw}}$ & $0.9 \pm 0.1^{\mathrm{ax}}$ & $1.3 \pm 0.1^{\text {ay }}$ & $8.0 \pm 1.1^{\mathrm{aw}}$ & $11.6 \pm 2.0^{\mathrm{aw}}$ \\
\hline
\end{tabular}

${ }^{*}$ Permissible limit of $\mathrm{Pb}(500 \mu \mathrm{g} / \mathrm{kg})(38)$.

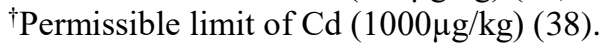

$\$$ Permissible limit of As $(1000 \mu \mathrm{g} / \mathrm{kg})(38)$.

Values are expressed as Mean \pm SD.

Means within the same column with different superscripts are significantly different $(\mathrm{P}<0.05)$.

Means within the same row with different superscripts are significantly different $(\mathrm{P}<0.05)$.

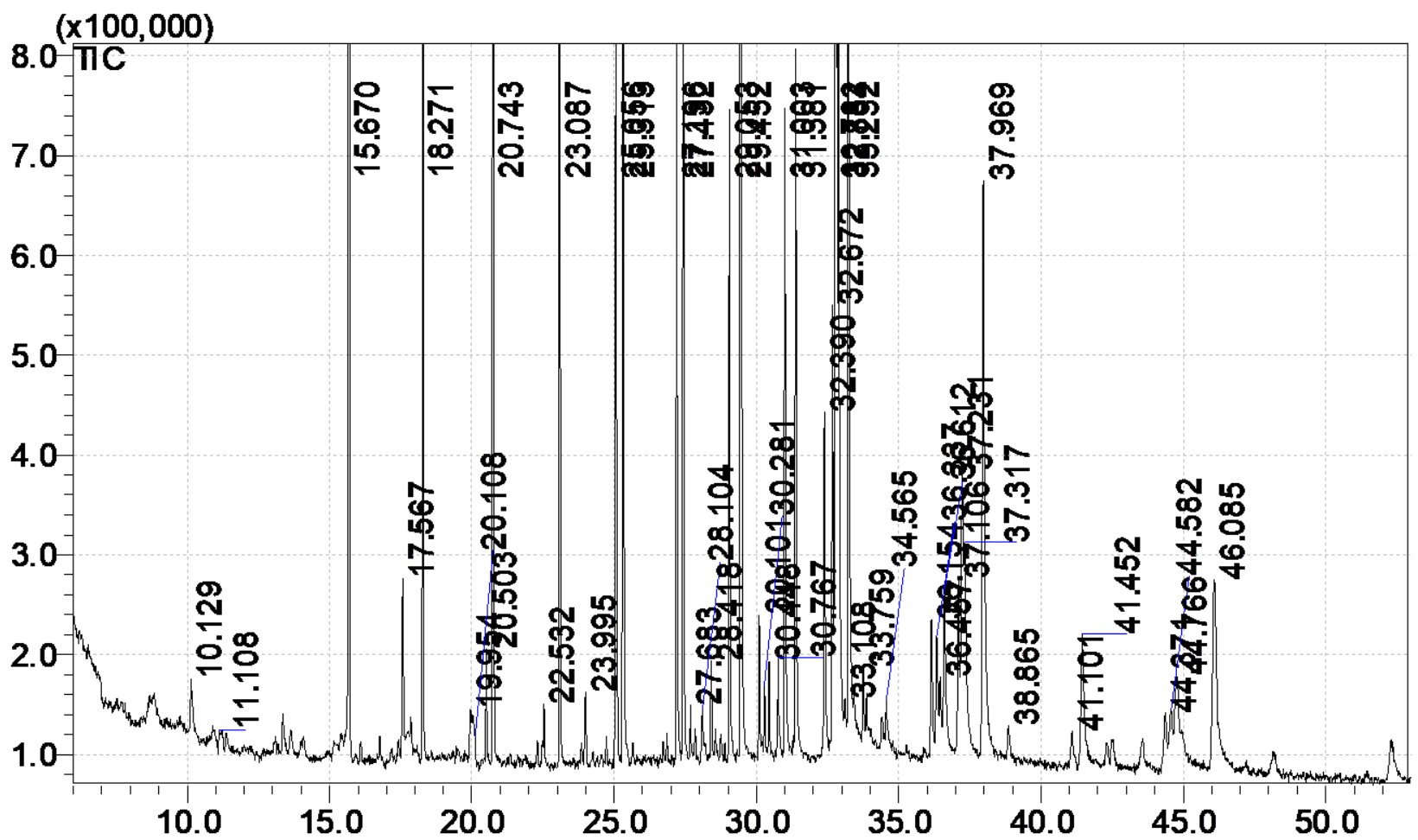

Figure 1: GC/MS chromatogram of investigated pesticides standards

\section{Conclusion}

The current study concludes the existence of pesticide residues and toxic metal residues in muscle and liver tissues of sheep, cattle and dromedary camel carcasses at Al-Ahsa governorate. Diazinon contaminated muscle and liver tissues of all examined carcasses. Other pesticide residues differed according to the areas that animals originated. The heavy metal loads were species independent. The concentrations of $\mathrm{Pb}$ and $\mathrm{As}$ in liver tissues were comparable to that of muscle tissues of all tested animals. However, the concentration of $\mathrm{Cd}$ in liver was significantly higher than its concentration in muscle in all tested animals. Consumption of carcasses is safe to human health because the detected pesticide and toxic metal residues were well below international permissible limit. 


\section{Acknowledgments}

The authors thank the Deanship of Scientific Research in King Faisal University, Saudi Arabia, for their support of this study (Project\# DSR130025).

\section{References}

1. Saggu S, Rehma H, Alzeiber FMA, Aziz A. Current situation of pesticide consumption and poisoning in Saudi Arabia. Journal of Entomology and Zoology Studies 2016; 4(3): 153-8.

2. Mozib M, El-Shafie HA. Effect of red palm weevil, Rhynchophorusferrugineus (Olivier) infestation on temperature profiles of date palm tree. Journal of Entomology and Nematology 2013; 5(6): 77-3.

3. Jian-Ying H, Takako A, Yasumoto M. Analysis of pesticides in water with liquid atmospheric pressure chemical ionization mass spectrometry. Water Research 1999; 33(2): 417-25.

4. WHO (World Health Organization). Health risks of heavy metals from long-range trans boundary air pollution, 9789289071796 WHO Regional Office for Europe, Copenhagen, Denmark, 2007.

5. Miyahara M, Saito Y. Effects of the processing steps in tofu production on pesticide residues. Journal of Agricultural and Food Chemistry 1994; 42(2): 369-73.

6. Gilbert L, Gracia B, Mezcua M, Ramos N, Fernandez AR, Molina A. Multi-residue determination of pesticides in fruit-based soft drinks by fast liquid chromatography time-of-flight mass spectrometry. Talanta 2010; 81: 1310-1321.

7. Herdman, RC, Pahrham, WE, Shen S. Pesticide Residues in Food: Technologies for Detection. Government Printing Office, Washington, 1988.

8. Tao S, Liu, WX, Li XQ, Zhou DX, Li X, Yang YF, Yue DP, Coveney RM. Organochlorine pesticide residuals in chickens and eggs at a poultry farm in Beijing, China. Environmental Pollution 2009; 157: 497-502.

9. Sallam KI, Morshedy AMA. Organochlorine pesticide residues in camel, cattle and sheep carcasses slaughtered in Sharkia Province, Egypt. Food Chemistry 2008; 108: 154-64.

10. Shinde AK, Karim SA. Screening of pesticide residues in meat and milk samples of sheep maintained in institute and field flocks. Indian Journal of small ruminants 2009; 15(1): 924.

11. Jadhav VJ, Waskar VS. Public Health Implications of Pesticide Residues in Meat. Veterinary World 2011; 4(4): 178-82.
12. Elgasim EA, Alkanhal MA. Proximate composition, amino acids and inorganic mineral content of Arabian camel meat: comparative study. Food Chemistry 1992; 45(1): 1-4.

13. European Food Safety Authority-EFSA. Scientific opinion on arsenic in food. EFSA panel on contaminants in the food chain (CONTAM). European Food Safety Authority 2009a; 1351: 1-199.

14. European Food Safety Authority-EFSA. Opinion of the Scientific Panel on Contaminants in the Food Chain on a request from the Commission related to lead as undesirable substance in animal feed. European Food Safety Authority 2004; 72: $1-24$.

15. Mehennaoui, S, Charles E, Joseph-Enriquez B, ClauwM, Milhaud GE. Indicators of lead, zinc and cadmium exposure in cattle I and II. Veterinary and Human Toxicology 1988; 30: 550-5.

16. Rumbeiha, WK, Braselton, WE, Donch D. A retrospective study on the disappearance of blood lead in cattle with accidental lead toxicosis. Journal Veterinary Clinical Investigations 2001; 13: 373-8.

17. Nilsson U, Attewell R, Christoffersson JO, Schultz A, Ahlgren L, Skerfving S, Mattsson S. Kinetics of lead in bone and blood after end of occupational exposure. Pharmacological and Toxicological 1991; 68: 477-84.

18. Rabinowitz MB. Toxicokinetics of bone lead. Environmental Health Perspectives 1991; 91: 33-7.

19. Nakamori T, Kaneko N. Biomarker responses reveal that food quality affects cadmium exposure in soli collembolan Folsomia candida. Environmental Pollution 2013; 176: 165-70.

20. European Food Safety Authority-EFSA. Cadmium in food. Scientific opinion of the panel on contaminants in the food chain. European Food Safety Authority 2009b; 980: 1-139.

21. El-Ghareeb WR, Darwish WS, Meligy AMA. Metal contents in the edible tissues of camel and sheep: human dietary intake and risk assessment in Saudi Arabia. Japanese Journal of Veterinary Research 2019; 67(1): in press

22. Stan HJ. Pesticide residue analysis in foodstuffs applying capillary gas chromatography with mass spectrometric detection state-of-the-art use of modified DFG-multimethod S19 and automated data evaluation. Journal of Chromatography A 2000; 892: 347-77.

23. Albero B, Sanchez-Brunete C, Tadeo JL. Determination of organopho- sphorous pesticides in fruit juices by matrix solid-phase dispersion and gas chromatography. Journal of Agricultural and Food Chemistry 2003; 51: 6915-21. 
24. Pugliese P, Molto' JC, Damiani P, Maine R, Cossignani L, Manes J. Gas chromatographic evaluation of pesticide residue contents in nectarines after non-toxic washing treatment. Journal of Chromatography A 2004; 1050:185-91.

25. Rial-Otero R, Arias-Estevez M, Lopez-Periago E, Cancho-Grande B, Simal- Gandara J. Variation in concentrations of the fungicides tebuconazole and dichlofuanid following successive applications to greenhouse-grown lettuces. Journal of Agricultural and Food Chemistry 2005; 53 (11): 4471-5.

26. Balinova A, Mladenova R, Shtereva D. Solid-phase extraction on sorbents of different retention mechanisms followed by determination by gas chromatography-mass spectrometric and gas chromatography-electron capture detection of pesticide residues in crops. Journal of Chromatography A 2007; 1150: 136-44.

27. Pose-Juan E, Cancho-Grande B, Rial-Otero R, Simal-Gandara J. The dissipation rates of cyprodinil, fludioxoni, procymidone and vinclozoline during storageofgrapejuice. Food Control 2006; 17(12):1012-7.

28. Berrada H, Fernandez M, Ruiz MJ, Molto' JC, Manes J, Font G. Surveillance of pesticide residues in fruits from Valencia during twenty months (2004/05). Food Control 2010; 21: 36-44.

29. Menezes FA., Neves F, Afonso de Paula Pereira $P$. Development, validation and application of a methodology based on solid- phase micro extraction followed by gas chromatography coupled to mass spectrometry (SPME/GC-MS) for the determination of pesticide residues in mangoes. Talanta 2010; 81: 346-54.

30. Lazartigues A, Fratta C, Baudot R, Wiest L, Feidt C, Thomas M, Cren-Olivé C. Multiresidue method for the determination of 13 pesticides in three environmentalmatrices: water, sediments and fish muscle. Talanta 2011; 85(3):1500-7.

31. El-Bahr SM, Abdelghany AM. Heavy metal and trace element contents in edible muscle of three commercial fish species, and assessment of possible risks associated with their human consumption in Saudi Arabia. Journal of Advanced Veterinary and animal Research 2015; 2: 271-8.

32. Meligy AMA. Comparative study of element contents in seven isolates of entomopathogenic nematodes. Egyptian Journal of Biological Pest Control 2018; 28:1

33. Guo FP, Yan ZC, Jin JZ, Chun LF, Yong ML, Xue ML, Guang QJ, Zeng YL, Yu QS, Yan PW, Tong TG. Validation study on 660 pesticide residues in animal tissues by gel permeation chromatography cleanup/gas chromatography-mass spectrometry and liquid chromatography-tandem mass spectrometry. Journal of Chromatography A 2006; 1125: 1-30.

34. Al- Wabel, MI, El- Saeid, MH, Al- Turki AM, Abdel- Nasser G. Monitoring of Pesticide Residues in Saudi Arabia Agricultural Soils. Research Journal of Environmental Sciences 2011; 5: 269-78.

35. Mansour SA, Belal MH, Abou-Arab AAK, Gad MF. Monitoring of pesticide and heavy metals in cucumber fruits produced from different farming system. Chemosphere 2009; 75: 601-9.

36. Murray RK, Bender DA, Botham, KM, Kennelly PJ, Rodwell VW, Weil PA. Harper's Illustrated Biochemistry (Harper's Biochemistry). 28th ed., McGgraw-Hill, 2012.

37. Korsrud G, Meldrum J, Salisbury C. Trace element levels in liver and kidney from cattle, swine and poultry slaughtered in Canada. Canadian Journal of Comparative Medicine 1985; 49: 159-63.

38. Filho JFA, Germano A, Dibai WLS, Vargas EA, Melo MM. Heavy metals investigation in bovine tissues in Brazil. Food Science and Technology (Campinas) 2014; 34(1): 110-5. 